\title{
Foreword: Becoming a post-Keynesian economist with Marc Lavoie
}

\author{
Eckhard Hein
}

It is a great honour and pleasure to contribute this foreword to Marc Lavoie's selected essays on Post-Keynesian Growth Theory. I am very grateful to Louis-Phillipe Rochon for the invitation to adapt my contribution to a panel celebrating Marc's retirement from the University of Paris 13 and from running the International Master Programme 'Economic Policies in the Age of Globalisation (EPOG)' at the joint AFEP, IIPPE and AHE conference in Lille, 3-5 July 2019, for this purpose.

This contribution is a very personal review on my connections and collaborations with Marc Lavoie, which is partly chronological and partly not. I have never been formally a graduate student under the supervision of any eminent international post-Keynesian, but I moved towards post-Keynesian economics more or less on my own, studying the important works of Marx, Keynes, Kalecki, Harrod, Kaldor, Robinson, Sraffa, Steindl, and those of the then living post-Keynesians. Only at a later stage in my career, after I had obtained my German doctoral degree, I got in personal contact with the leading international post-Keynesians, whom I had studied extensively before, like Amit Bhaduri, Basil Moore, Philip Arestis, Malcolm Sawyer, Tom Palley, Amitava Dutt, Robert Blecker, Steve Fazzari, and several others. But with hindsight, it was the work of and then the personal contact with Marc Lavoie that left the largest impression on me. Therefore, I will shed some light on Marc's most important contributions to post-Keynesian economics from my very subjective perspective, and also on some of his activities on the European side of the Atlantic Ocean. What I have to present will not attempt to be comprehensive at all, and maybe it will tell more about me than about Marc - apologies for that in advance. ${ }^{1}$

\section{Studying Marc Lavoie's work before meeting him (1992-2000)}

In the first half of the 1990s, I did my dissertation work at the Free University of Berlin on Money, Effective Demand and Capital Accumulation: Considerations from Marx's, Keynes's and Post-Keynesian Perspectives. I was supervised by a Marxian economist, Klaus Peter Kisker, and the German Monetary Keynesian Hajo Riese acted as a second supervisor. Having worked through Marx and Keynes, I got somewhat lost with all those post-Keynesian contributions, the different strands, the controversies around endogenous money and exogenous interest rates, the different views on the treatment of capacity utilisation as an endogenous variable beyond the short run, etc. Then, however, I discovered Marc Lavoie's (1992) book, Foundations of Post-Keynesian Economic Analysis, which was an eye-opener and guide for many years. In effect, in the introduction of my dissertation, which then was published as a book in German (Hein 1997), ${ }^{2}$ I subscribed to what Marc had called a 'postclassical' approach to economics according to four presuppositions: the epistemology follows realism instead of neoclassical instrumentalism, the ontology is classified as organicism 
instead of individualism, the rationality as procedural rationality instead of substantive rationality, and the focus of analysis is seen to be on production as opposed to the neoclassical focus on exchange. Built on that, I then discussed the differences and commonalities of Marx's and Keynes's contributions on money, effective demand, distribution and capital accumulation, and got into the different strands of post-Keynesian economics, with a focus on the Kaleckian tradition in particular.

Of course, in this period I studied Marc Lavoie's papers on endogenous money - and always found his arguments in favour of horizontalism most convincing, in particular those exposed in Lavoie (1996). However, what attracted me most in Marc's work were his attempts at including monetary variables, interest and credit, into Kaleckian models of distribution and growth. That is what I was struggling with in my own dissertation work. In this context, I had discovered the modern Kaleckian distribution and growth models as a bridge between Marx and Keynes, allowing one to deal with distributional conflict and the principle of effective demand in a unified framework, and with the Bhaduri/Marglin (1990) and Kurz (1990) models even allowing for different regimes, wage- or profit-led. Yet all of this was missing an explicit role for money, credit and interest. Marc's contribution to a book edited by Rühl and Mongiovi (Lavoie 1993), and in particular his paper in Metroeconomica (1995, Chapter 6 this volume) paved the way for my own work. On the one hand, I changed the accumulation function of Marc's models starting with the post-Kaleckian Bhaduri/Marglin investment function, and on the other hand, I introduced an interest-elastic mark-up, which gave rise to further variations and cases for the model - the usual $\mathrm{PhD}$ work. ${ }^{3}$

\section{Meeting Marc and keeping personal contact ever since (2001- )}

Since I was somewhat of a latecomer with regard to participating in international conferences, the first time I met Marc in person was at a conference at the Free University of Berlin in late March 2001, celebrating the retirement of Hajo Riese. The conference was organised by Victoria Chick who then had a visiting professorship at the Free University. At that conference, I also met some other eminent post-Keynesians for the first time; I remember, in particular, Basil Moore and a young Giuseppe Fontana. All of them were very friendly and it was a pleasure to talk to them - the international post-Keynesian community was so different from German mainstream academics with its dominant orthodox views and hierarchies.

Most importantly, I was impressed by Marc's openness and his interest in my own work and struggles. I think this was when we started to exchange e-mails and I, as the younger post-doc, started to send my ideas and paper drafts to him for comments. In these exchanges, I had to learn that Marc had worked on many areas and questions which I found interesting. Most importantly, he had already published papers on issues that I was just starting to think about. Therefore, at some point, before starting to work on an elaboration of my own models, I used to ask him first, whether he had already done what I had in mind! Sometimes he said yes, but sometimes also no - maybe there were more 'yes' than 'no'? I don't remember.

In this period, the early 2000s, Marc, among other things, was working on his book with Wynne Godley on Monetary Economics: An Integrated Approach to Credit, Money, Income, Production and Wealth (Godley/Lavoie 2007), which became the reference work for modern stock-flow consistent (sfc) modelling. In the same period, I was working on a book on Money, Distribution Conflict and Capital Accumulation: Contributions to 'Monetary Analysis' (Hein 2008), using simple small-scale analytical models, which, at least I hope, are also stock-flow 
consistent. But I did not apply sfc simulation models. Of course, needless to say that the Godley/Lavoie book had a much bigger impact on the post-Keynesian community than my own slim little volume.

\section{Working with Marc I: Defending the Kaleckian model against Harrodian and Marxian critics (2008- )}

Since the early 2000s Marc and I had regularly met at conferences, in Berlin, Copenhagen, Dijon, New York, etc., and we thought that we should spend some time together in order to have more time for discussions and also to try some joint work. Therefore, in May/June 2008, together with my then PhD student Till van Treeck, we visited Marc at the University of Ottawa for two weeks. During these two weeks, we worked on a joint project on instability issues in Kaleckian models, but we also spent some leisure time together. I remember the nice barbecue with Camille and Marc in their house and the billiards we played in the basement. Marc also took us to Montreal and on our way back we watched a fencing world cup tournament - it is well known that Marc had been an Olympic fencer in the 1970s/80s, and so we learnt a lot about fencing, too!

But we also did serious academic work. Marc had already dealt with the Marxian and Harrodian critique of an endogenous rate of capacity utilisation in the Kaleckian distribution and growth model beyond the short run (Lavoie 1995, Chapter 1 this volume; 1996, Chapter 2 this volume). In these papers, he showed that the supposed Harrodian instability would be contained by an endogenous adjustment of the firms' assessment of the normal rate of utilisation. I had two papers on the endogeneity of the 'stable inflation rate of employment' (SIRE) and the 'stable inflation rate of capacity utilisation' (SIRCU) (Hein 2006c, 2006d), which in the Duménil/Lévy (1999) Harrodian/Classical models were considered to determine the normal or target rate of capacity utilisation. ${ }^{4}$ Moreover, Till van Treeck, together with Thomas Dallery, had been working on a paper based on Marc's chapter in a book edited by Mark Setterfield (Lavoie 2002), arguing that firms have multiple targets in the long run, the achievement of which may be mutually inconsistent (Dallery/van Treeck 2011). Therefore, we decided to join forces and to provide a comprehensive review and critique of the different Harrodian/Marxian models, on the one hand, and a systematic presentation of the Kaleckian responses and defenses, on the other hand. For publication, we had to split the long working paper we had produced. The first part dealing with a critique of Harrodian/Marxian models by Duménil/Lévy (1999), Shaikh (2009) and Skott (2010,2012) was published in the Cambridge Journal of Economics (Hein/Lavoie/van Treeck 2011). The second part, providing a survey of Kaleckian solutions, came out in Metroeconomica (Hein/Lavoie/van Treeck 2012). ${ }^{5}$

However, Marc was not content with this state of the debate and so continued to contribute to it. In his later work, he introduced the main idea of the Sraffian super-multiplier models, the notion that growth is driven by an autonomous growth rate of non-capacity creating demand (autonomous consumption, residential investment, government expenditures or exports), into Kaleckian distribution and growth models. In Lavoie (2016, Chapter 9 this volume) and several joint papers with Won Jun Nah (Chapters 10-13 in this volume), he showed that these models allow for taming Harrodian instability under certain weak conditions, adjusting the economy to some given normal rate of utilisation in the long run. Most importantly, these models allow for preserving the Kaleckian results with respect to the paradox of saving and the paradox of cost at least for the growth path, but not for the growth rate. Such models may 
have good explanatory power when it comes to explaining the observed data (Chapter 14 this volume). What has been missing in these models, however, was the financing of autonomous demand growth and the related debt dynamics. I have started some work on this (Hein 2018b, Hein/Woodgate 2021), and I am grateful to Marc for his comments on some of the drafts.

\section{Working with Marc II: The ILO project on wage-led growth (2011-2012)}

I think in late 2010 Marc approached me and told me that some people at the ILO had asked him to run a project on 'wage-led growth', as an alternative to the growth regimes that had led us into the 2007-09 financial crisis and the Great Recession, the debt-led private demand boom regime and the export-led mercantilist regime. We were all very excited that a UN organisation was interested in post-Keynesian work on wage-led and profit-led growth, and Marc, together with Engelbert Stockhammer, set up a group of researchers, including Özlem Onaran with Giorgos Galanis, Servaas Storm and Ro Naastepad, Simon Sturn and Till van Treeck, and myself with Mathias Mundt, a then graduate student of mine. We produced long working papers for the ILO on the concept of wage-led growth, on the determinants of falling wage shares, on the nature of the demand regimes in OECD countries, on productivity growth issues within this concept, on the role of overall income inequality and on financialisation, the crisis and the requirements for wage-led growth. Marc, together with Engelbert, produced a very helpful and valuable piece clarifying some of the basic issues (Lavoie/Stockhammer 2013a), which I am still using for teaching purposes, and they co-edited a book on Wage-led Growth: An Equitable Strategy for Economic Recovery (Lavoie/Stockhammer 2013b) containing shortened versions of all our contributions. Most importantly, we presented the project at an ILO conference in Geneva in 2012 and several results of the project were then picked up by the ILO (2012) Global Wage Report: Wages and Equitable Growth. I think it was through this project that Marc got involved a bit more into the wage-led/profit-led demand and growth debate in post-Keynesian economics, from which he had abstained so far, and contributed some more conceptual and theoretical work (Lavoie 2017, Chapter 5 this volume).

\section{Working with Marc III: Textbooks on Post-Keynesian Economics and Distribution and Growth after Keynes (2012-2014)}

In 2012, both Marc and I started to work on some textbooks. He produced an updated and extended version of his 1992 book which then became Post-Keynesian Economics: New Foundations (Lavoie 2014), and I was working on a translation, update and extension of a 2004 German book on distribution and growth (Hein 2004b), which then was published as Distribution and Growth after Keynes: A Post Keynesian Guide (Hein 2014). In this process, we exchanged draft chapters of our books and commented extensively on each other's drafts. I must say that I benefitted a whole lot from Marc's insightful comments and suggestions. In the course of this process, we had the chance to work and discuss intensively when Marc visited Berlin for the FMM summer school 2013 (more below), coming a couple of days earlier and staying at my place. This was a very hot summer in Berlin, and I remember that we stayed in the apartment in the morning reading and discussing, but then we went out and, among other activities, had a nice and sunny boat-trip on the lakes between Berlin and Potsdam. In late 2014, we jointly presented our books at the annual FMM conference in Berlin. Guess which book has had a bigger impact on the community since then? Looking at Google Scholar quotations in late July 2021, my book has had 250 quotes, whereas Marc's has 
had 1102 - no surprise to me at all! Two shorter joint pieces emanated from this collaboration, too: A contribution on post-Keynesian economics to The Elgar Companion to John Maynard Keynes, edited by Robert Dimand and Harald Hagemann (Hein/Lavoie 2019), and a chapter on post-Keynesian theories and policies of full employment in a Swedish book, edited by Tony Johansson, on wage bargaining beyond the NAIRU (Lavoie/Hein 2015).

\section{Working with Marc IV: FMM summer schools, EJEEP and EPOG (2008- )}

Marc has not only produced dozens of eminent papers and several important books, he has also contributed to building and stabilising the post-Keynesian community. In 2008, Torsten Niechoj, Engelbert Stockhammer and I, with the financial and administrative support of the Hans Boeckler Foundation, started with the Berlin graduate students summer schools of the FMM, the Forum for Macroeconomics and Macroeconomic Policies (then the Research Network Macroeconomics and Macroeconomic Policies). Since 2009, these summer schools have taken place every second year - except for the Corona crisis year 2021. Marc has been a continuous lecturer at the FMM summer schools since the very beginning, usually taking over the opening lecture on 'History and method of post-Keynesian economics' or the one on 'Money, credit and central banks in post-Keynesian economics', or even both. These were also the chapters he contributed to the 'summer school book', which Engelbert and I edited, A Modern Guide to Keynesian Macroeconomics and Economic Policies (Hein/Stockhammer 2011). We all, and in particular the summer school students, appreciated that Marc usually stayed for the whole week at the very nice summer school location - with access to a lake and was thus always available for discussions.

During the summer schools, Marc and I used to do some sports, usually jogging every second day before breakfast. Then, I think it was in 2015, Marc asked me whether I would like to play some tennis. I knew that he had become almost a 'semi-professional player' in order to keep up with his wife Camille, also a 'semi-professional'. I had played some tennis since I was in my early twenties, but only at a low level and I had not actively practised for a couple of years, so my expectations were not very high. To be honest, I don't remember the exact results of our matches anymore: Was it 6-0, 6-0 or did I manage at least a 6-1, 6-0? Anyway, although I had no chance whatsoever, at least I had some fun. I am not sure whether this was also true for Marc...

In 2012, Marc also joined the board of managing editors of the European Journal of Economics and Economic Policies: Intervention (EJEEP), a journal which had been set up by some young German and Austrian colleagues in 2004, and which I had joined in 2008. In the course of the years, Marc's experience has helped a whole lot in improving the quality of the journal. He has organised and edited several special issues, and he has taken over responsibility for the review process of many papers. Together we have done several interviews with senior post-Keynesian colleagues, like Robert Blecker, Amitava Dutt, John McCombie and Tom Palley, and published them in the journal (Hein/Lavoie 2015, 2016, 2018, 2020). I think we both consider these interviews as an important feature of EJEEP, and maybe for the identity of the post-Keynesian community, too.

Finally, I have to mention the Erasmus Mundus Master Economic Policies in the Age of Globalisation (EPOG). When the main coordinator of EPOG, David Flacher, left the University of Paris 13, a senior professor was meant to take over, and it was Marc who had to take on this new role. I remember that he first bitterly complained, because running a programme was not 
exactly what he had come to Paris 13 for! But then he accepted 'the normative power of facts' (as the Marxians used to say) - and he helped to stabilise the programme, together with his colleagues at the University of Paris 13 and at the other universities involved, among them my Berlin School of Economics and Law.

\section{Perspectives}

I am very glad that I have had the privilege to meet Marc and to work with him a bit. I sincerely hope that this will continue for a long time to come! I am grateful for his help, support and friendship. I am sure Marc will continue to contribute to post-Keynesian economics - not only with this selection of important essays on distribution and growth. Currently he is working on another edition of his Foundations of Post-Keynesian Economics and I am looking forward to reading and discussing it - and to working with him in the context of EJEEP, FMM summer schools and beyond.

\section{Notes}

1. For further aspects of Marc's work and life, see the interview I did with Marc for our journal, the European Journal of Economics and Economic Policies: Intervention (Hein 2018a).

2. Two later English papers summarised some of my findings with regard to Marx, Keynes and the post-Keynesian (Hein 2004a, 2006a), and I made another somewhat broader attempt at linking Marx and the post-Keynesians recently (Hein 2019).

3. A further elaborated and refined English version of my work was published somewhat later as Hein (2007) and companion piece using a neo-Kaleckian model setting as Hein (2006b).

4. This model had also been criticised by Lavoie/Kriesler (2007, Chapter 8 this volume).

5. If I remember correctly, we did not only work on our joint project but we also discussed our contributions to Mark Setterfield's Handbook of Alternative Theories of Economic Growth, to which we were invited to contribute (Hein/van Treeck 2010, Lavoie 2010).

\section{Bibliography}

Bhaduri, A., Marglin, S. (1990), 'Unemployment and the real wage: The economic basis for contesting political ideologies', Cambridge Journal of Economics, 14, 375-93.

Dallery, T., van Treeck, T. (2011), 'Conflicting claims and equilibrium adjustment processes in a stock-flow consistent macro model', Review of Political Economy, 23, 189-211.

Duménil, G., Lévy, D. (1999), 'Being Keynesian in the short term and classical in the long term: The traverse to classical long-term equilibrium', Manchester School of Economic and Social Studies, 67, 684-716.

Fiebiger, B., Lavoie, M. (2019), 'Trends and cycles with external markets: Non-capacity generating semi-autonomous expenditures and effective demand', Metroeconomica, 70 (2), 247-62.

Godley, W., Lavoie, M. (2007), Monetary Economics. An Integrated Approach to Credit, Money, Income, Production and Wealth, Basingstoke: Palgrave Macmillan.

Hein, E. (1997), Geld, effektive Nachfrage und Kapitalakkumulation. Eine Betrachtung aus Marxscher, Keynesscher und post-Keynesianischer Perspektive, Berlin: Duncker \& Humblot.

Hein, E. (2004a), 'Money, credit and the interest rate in Marx's economics: On the similarities of Marx's monetary analysis to post-Keynesian economics', International Papers in Political Economy, 11 (2), 1-43.

Hein, E. (2004b), Verteilung und Wachstum: Eine paradigmenorientierte Einfuihrung unter besonderer Berücksichtigung der post-Keynesianischen Theorie, Marburg: Metropolis.

Hein, E. (2006a), 'Money, interest and capital accumulation in Karl Marx's economics: A monetary interpretation and some similarities to post-Keynesian approaches', European Journal of the History of Economic Thought, 13 (1), 113-40.

Hein, E. (2006b), 'Interest, debt and capital accumulation - a Kaleckian approach', International Review of Applied Economics, 20, 337-52.

Hein, E. (2006c), 'On the (in-)stability and the endogeneity of the "normal" rate of capacity utilisation in a postKeynesian/Kaleckian "monetary" distribution and growth model', Indian Development Review, 4, 129-50.

Hein, E. (2006d), 'Wage bargaining and monetary policy in a Kaleckian monetary distribution and growth model: Trying to make sense of the NAIRU', Journal of Economics: Intervention, 3, 305-29.

Hein,E. (2007), 'Interest rate, debt, distribution and capital accumulation in a post-Kaleckian model', Metroeconomica, 
$\mathbf{5 8}, 310-39$.

Hein, E. (2008), Money, Distribution Conflict and Capital Accumulation: Contributions to 'Monetary Analysis', Basingstoke: Palgrave Macmillan.

Hein, E. (2014), Distribution and Growth after Keynes: A Post-Keynesian Guide, Cheltenham, UK and Northampton, MA, USA: Edward Elgar Publishing.

Hein, E. (2018a), 'Interview with Marc Lavoie: The vigorous critique of the neo-Kaleckian or post-Kaleckian growth model is a measure of its success', European Journal of Economics and Economic Policies: Intervention, 15 (1), $2-11$.

Hein, E. (2018b), 'Autonomous government expenditure growth, deficits, debt and distribution in a neo-Kaleckian growth model', Journal of Post Keynesian Economics, 41 (2), 216-38.

Hein, E. (2019), 'Karl Marx - an early post-Keynesian? A comparison of Marx's economics with the contributions by Sraffa, Keynes, Kalecki and Minsky', European Journal of Economics and Economic Policies: Intervention, 16 (2), 238-59.

Hein, E., Lavoie, M. (2015), 'Interview with John McCombie: I think there's absolutely no way out for them: An aggregate production function does not make any sense at all!', European Journal of Economics and Economic Policies: Intervention, 12 (1), 1-6.

Hein, E., Lavoie, M. (2016), 'Interview with Thomas I. Palley: We need to confront more forcefully the neoclassical position and show the absolute impossibility of the world they describe!', European Journal of Economics and Economic Policies: Intervention, 13 (3), 255-64.

Hein, E., Lavoie, M. (2018), 'Interview with Robert A. Blecker: People will come searching for us post-Keynesians if the political atmosphere is encouraging', European Journal of Economics and Economic Policies: Intervention, 15 (3), 250-58.

Hein, E., Lavoie, M. (2019), 'Post-Keynesian economics', in: H. Hagemann and R. Dimand (eds), The Elgar Companion to John Maynard Keynes, Cheltenham, UK and Northampton, MA, USA: Edward Elgar Publishing, pp. 540-46.

Hein, E., Lavoie, M. (2020), 'Interview with Amitava K. Dutt: I never held models as depictions of anything real; models are just to understand some mechanisms', European Journal of Economics and Economic Policies: Intervention, 17 (3), 278-85.

Hein, E., Lavoie, M., van Treeck, T. (2011), 'Some instability puzzles in Kaleckian models of growth and distribution: A critical survey', Cambridge Journal of Economics, 35, 587-612.

Hein, E., Lavoie, M., van Treeck, T. (2012), 'Harrodian instability and the "normal rate" of capacity utilisation in Kaleckian models of distribution and growth - a survey', Metroeconomica, 63, 139-69.

Hein, E., Stockhammer, E. (2011) (eds), A Modern Guide to Keynesian Macroeconomics and Economic Policies, Cheltenham, UK and Northampton, MA, USA: Edward Elgar Publishing.

Hein, E., van Treeck, T. (2010), "Financialisation" in post-Keynesian models of distribution and growth - a systematic review', in M. Setterfield (ed.), Handbook of Alternative Theories of Economic Growth, Cheltenham, UK and Northampton, MA, USA: Edward Elgar Publishing.

Hein, E., Woodgate, R. (2021), 'Stability issues in Kaleckian models driven by autonomous demand growth Harrodian instability and debt dynamics', Metroeconomica, 72 (2), 388-404.

ILO (2012), Global Wage Report: Wages and Equitable Growth, Geneva: ILO.

Kurz, H.D. (1990), 'Technical change, growth and distribution: A steady-state approach to "unsteady" growth', in H.D. Kurz, Capital, Distribution and Effective Demand, Cambridge, UK: Polity Press.

Lavoie, M. (1992), Foundations of Post Keynesian Economic Analysis, Cheltenham, UK and Northampton, MA, USA: Edward Elgar Publishing.

Lavoie, M. (1993), 'A post-classical view of money, interest, growth and distribution', in G. Mongiovi and C. Rühl (eds), Macroeconomic Theory: Diversity and Convergence, Cambridge, UK: Cambridge University Press.

Lavoie, M. (1996), 'Horizontalism, structuralism, liquidity preference and the principle of increasing risk', Scottish Journal of Political Economy, 43, 275-300.

Lavoie, M. (2002), 'The Kaleckian growth model with target return pricing and conflict inflation', in M. Setterfield (ed.), The Economics of Demand-led Growth, Cheltenham, UK and Northampton, MA, USA: Edward Elgar Publishing.

Lavoie, M. (2010), 'Surveying long-run and short-run stability issues with the Kaleckian model of growth', in M. Setterfield (ed.), Handbook of Alternative Theories of Economic Growth, Cheltenham, UK and Northampton, MA, USA: Edward Elgar Publishing.

Lavoie, M. (2011a), 'History and methods of post-Keynesian economics', in E. Hein and E. Stockhammer (eds), A Modern Guide to Keynesian Macroeconomics and Economic Policies, Cheltenham, UK and Northampton, MA, USA: Edward Elgar Publishing.

Lavoie, M. (2011b), 'Money, credit and central banks in post-Keynesian economics', in E. Hein and E. Stockhammer (eds), A Modern Guide to Keynesian Macroeconomics and Economic Policies, Cheltenham, UK and Northampton, MA, USA: Edward Elgar Publishing. 
Lavoie, M. (2014), Post-Keynesian Economics: New Foundations, Cheltenham, UK and Northampton, MA, USA: Edward Elgar Publishing.

Lavoie, M., Hein, E. (2015), 'Vägen till full sysselsättning (The road to full employment)', in: T. Johansson (ed.), Lönebildning bortom NAIRU (Wage Bargaining beyond the NAIRU), Stockholm: Landsorganisationen Sverige (LO), pp. 134-53.

Lavoie, M., Stockhammer, E. (2013a), 'Wage-led growth: Concept, theories and policies', in: M. Lavoie and E. Stockhammer (eds), Wage-led Growth: An Equitable Strategy for Economic Recovery, Basingstoke: Palgrave Macmillan.

Lavoie, M., Stockhammer, E. (2013b) (eds), Wage-led Growth: An Equitable Strategy for Economic Recovery, Basingstoke: Palgrave Macmillan.

Shaikh,A. (2009), 'Economic policy in a growth context: Aclassical synthesis of Keynes and Harrod', Metroeconomica, 60, 455-94.

Skott, P. (2010), 'Growth, instability and cycles: Harrodian and Kaleckian models of accumulation and income distribution', in M. Setterfield (ed.), Handbook of Alternative Theories of Economic Growth, Cheltenham, UK and Northampton, MA, USA: Edward Elgar Publishing.

Skott, P. (2012), 'Theoretical and empirical shortcomings of the Kaleckian investment function', Metroeconomica, 63, 109-38. 